\title{
Entomopathogenic Fungus as A Biocontrol Agent Against The Cattle Tick Boophilus annulatus (Say) (Acari: Ixodidae)
}

\author{
Kawther M. El-Kammah and Laila M. I. Oyoun \\ Zoology and Agric. Nematology Dept., Fac. of Agriculture, Cairo University, Egypt, \\ E-mail: aas3rd@lycos.com
}

\begin{abstract}
Boophilus annulatus (Say) fed females were collected from healthy cattle (Bos indicus) and the eggs from their pin ground. Both were found infected with hyphae of Beauvaria bassiana, penetrating tick cuticles and egg membranes. Ticks were observed immobile and gradually died within 3-4 days. Eggs were dried within 48 hrs. The same symptoms were observed after exposing uninfected ticks with infected B. annulatus fed females and eggs. Females died within 4 to 5 days, while the eggs dried and never hatched. Results indicate that fungi can be used as an important biological control agent against the cattle ticks, B. annulatus.
\end{abstract}

KEY WORDS: Acari, Ixodidae, Boophilus annulatus (Say), ticks, entomophathogenic fungus, biological control, Egypt.

\section{INTRODUCTION}

Among the 840 known tick species in the world, the Boophilus species are the most important ticks affecting the economics of the cattle production in tropical and subtropical areas of the world. Each Boophilus species is a vector of Babesia bigemina, Anaplasma marginale Theiler, 1910, Borrelia theileri and probably transmit Babesia bovis. Heavy Boophilus infestation loads produce severe anemia, enervation and loss of weight in hosts. These ticks affect about 800 million cattle heads throughout the world. (Hoogstraal 1985 and Pegram et al. 1993).

In Egypt, the estimated number of cattle yearly exceeds 6.5 million heads (2002-2003, personal communication, Ministry of Agriculture, Animal Production Dept.), with a loss of meat protein estimated about 1200 tons annually, if only $50 \%$ of the cattle were infested. To control these ticks, chemical insecticides are extensively used which raise the cost of production plus the negative effects on health and environment.

Entomophathogenic fungi were repo-rted as biocontrol agents against ticks (Mwangi et al., 1995;
Kaaya et al.1996). The present work was undertaken to study the impact of the fungus Beauveria bassiana naturally found in the Egyptian fauna as biocontrol agent against cattle ticks, Boophilus annulatus (Say in Egypt).

\section{MATERIALS AND METHODS}

Boophilus annulatus ticks were collected from cattle (Bos indicus) grazing on the Faculty of Agriculture Farm, Cairo University, Giza, Egypt. The eggs were collected from soil and debris in the same cattle pin ground. All ticks and eggs were found infected with fungus. Samples of colonized clean ticks and eggs were mixed in autoclaved tubes with the infected samples for investigating the possibility of infection. All treated and untreated ticks and eggs were observed daily for survival and viability.

\section{RESULTS AND DISCUSSION}

Thirty field collected engorged $B$. annulatus females and 5 batches of eggs $( \pm 0.1 \mathrm{gm})$ were found

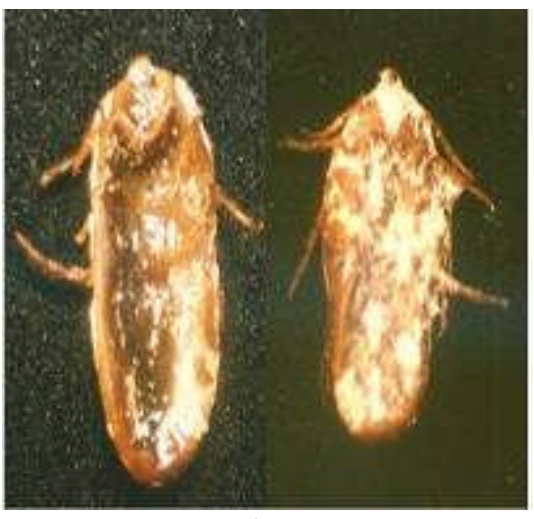

A

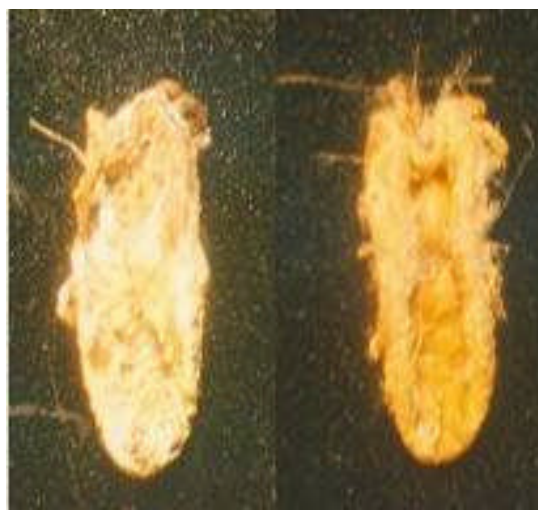

$\mathrm{B}$

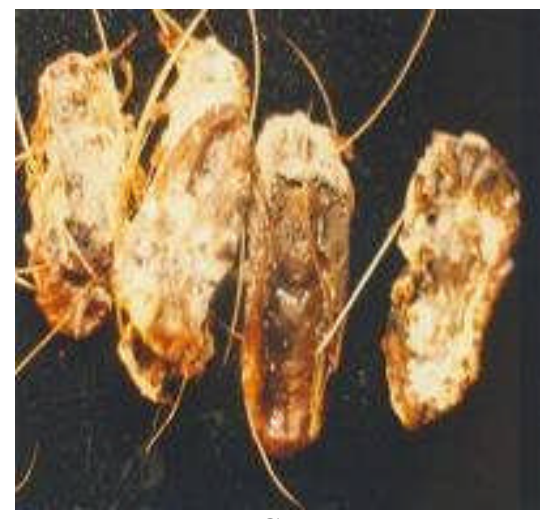

C

Fig. 1: A- Collected B. annulatus ticks infected with B. bassiana B- Gradual symptoms of illness, (2-3 days) C- Dead infected females (4 days 
A

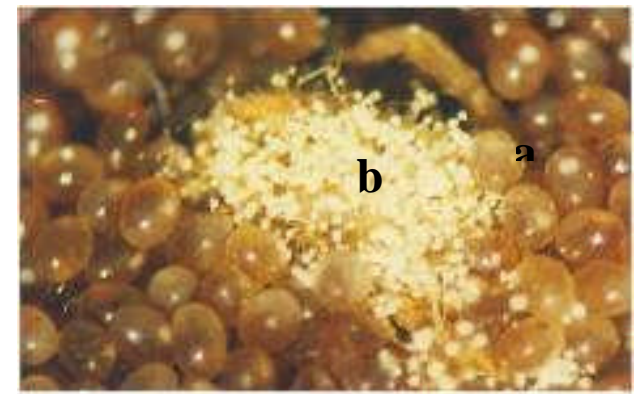

B

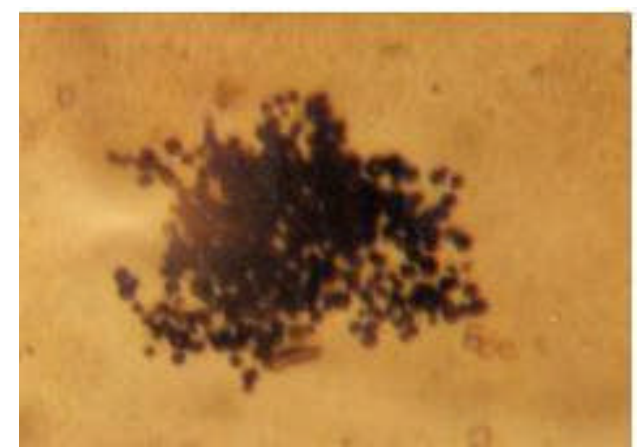

Fig. 2: A-Infected field collected B. annulatus eggs (a) with B. bassiana (b) B- Dried eggs after $48 \mathrm{hr}$

A

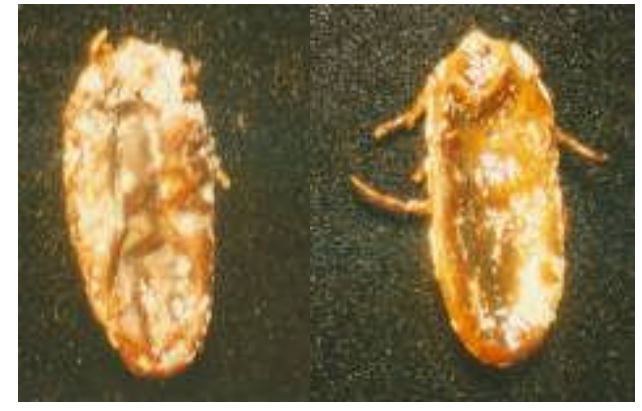

B

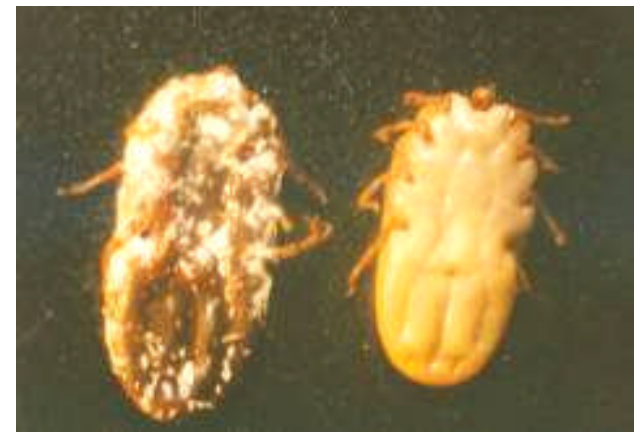

$\mathrm{C}$

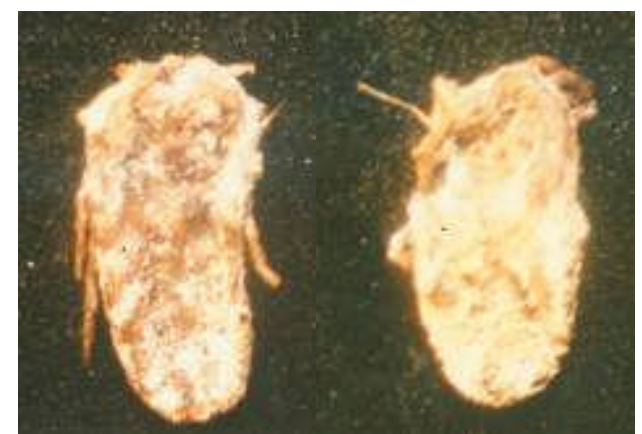

Fig. 3: A- Infected and uninfected B. annulatus females B-2-3 days post infection C- Dead females (4 days) naturally infected with Beauveria bassiana. The observed fungus penetrated the tick cuticle and egg membranes to obtain nutrients. The fungus was developing clearly while the ticks became weaker, then immobile, until 100\% died within 3-4 days (Fig.1). The eggs shrank until no fluid could be seen through their membranes in $24 \mathrm{hrs}$. The eggs looked non-vital and did not hatch, (Fig. 2). The same symptoms were observed on experimentally infected females and eggs, (Fig. 3). The host cattle remained as healthy as when they were infected with the ticks.

Tick control has been attempted through different techniques:

Acaricides: several methods have been, and still are in use. However, all of them lead to different difficulties, such as tick resistance and residual concentration in meat and/or other animal products such as milk or butter, which may reach human consumption.

Biological control: the use of pest/vector species, hormonal disruption, pheromone-baited devices and also molecular methods such as the vaccination of tick antigen are applied in limited areas and probably under experimental conditions, (Abdel Wahab et. al. 2000, Sayed et. al. 2001, and EL Kammah and Abdel Wahab, 2003).

Entomopathogenic fungi are used for tick biocontrol in different African countries,(Mwangi et. al. 1995 and Kaaya et. al. 1996). Studies in this area in Egypt are very limited, (Habeeb and Sewify 2002). Observing the present infection of $B$. annulatus ticks by fungus should encourage the evaluation of fungi as a biological control agent against ticks in Egypt. It caused death to females in few days and to embryo within $24 \mathrm{hr}$., which within cleavage developmental period as found by EL Kammah et. al. 1987.

Using $B$. bassiana as a biological control agent against the cattle tick $B$. annulatus seems to be fast, safe and successful (Table 1). Further studies are needed to clarify the efficiency of several fungus species against other tick species infesting farm animals. It is advised to use fungal culture found naturally in the Egyptian fauna to avoid external contamination.

Table 1: Effects of Beauvaria bassiana on the viability of the cattle tick Boophilus annulatus

\begin{tabular}{ccccc}
\hline \multirow{2}{*}{$\begin{array}{c}\text { B. bassiana } \\
\text { infection }\end{array}$} & \multicolumn{2}{c}{30 Fed females } & \multicolumn{2}{c}{$\begin{array}{c}\text { Five Egg batches } \\
( \pm 0.1 \mathrm{gm})\end{array}$} \\
\cline { 2 - 5 } & $\begin{array}{c}\text { Survival } \\
\text { Days (\%) }\end{array}$ & $\begin{array}{c}\text { Oviposition } \\
(\%)\end{array}$ & $\begin{array}{c}\text { Viability } \\
\text { (days) }\end{array}$ & $\begin{array}{c}\text { Hatching } \\
(\%)\end{array}$ \\
\hline Field Infected & $2-3(4)$ & - & 2 & - \\
\hline Control (Clean) & $21(100)$ & 100 & $15-20$ & 100 \\
\hline
\end{tabular}




\section{REFERENCES}

Abdel Wahab, K. S.; Habeeb, S. M. and El Kammah, K. M., 2000: Cattle natural immunity against the cattle tick Boophilus annulatus (Acari: Ixodidae): Detection of antibodies against Salivary gland and gut proteins using ELISA. Int J. Acarol. 26 (4): 345 - 389.

EL Kammah, K. M. and Abdel - Wahab, K. S E., 2003: Studies on the immune defence of chickens and Cattle against Argas persicus and Boophilus annulatus ticks (Acari: Ixodidae): Int. Insect Sci. Applic. 23 (1): 75-83.

EL Kammah, K. M; Gomma, E. A. and Oyoun, L. I., 1987: Embryonic development of the cattle tick Boophilus annulatus (Say) (Ixodoidea: Ixodidae) . Egypt. Histol. 10 (1): 77 - 81.

Habeeb, S. M. and Sewify, G.H. 2002: Biological control of the fowl tick Argas (Persicargas) persicus by the entomopathogenic fungi Beauveria bassiana and Metarhizium anisopliae. Egypt .J. Biol. Pest Control 12 (1) : 5-11.

Hoogstraal, H., 1985: Ticks. 1. Economic importance. In: Parasites, Pests and Predators, ed. S. M. Gaafer, W. . Howard and R. E. March.
Amesterdam: Elsevier:. 347-370.

Kaaya G. P., N. K. Mwangle and E. A. Ouna, 1996. Prospect for biological control of Livestock ticks, Rhicephalus append-iclatus and Amblyomma variegatum using the entomogenous fungi Beauveria bassiana and Metarhizium anisopliae. J. Inverber. Pathol. 67: 15-20.

Mwangi, E.N.; Kaaya, G. P.; Essuman, S. ;Kimondo; M. G. and Ouna, E. 1995: Experimental and natural infections of the tick Rhipicephalus appendiculatus with entomophathogenic fungi Beauveria bassiana and Metarhizium anisopliae and natural infection of some ticks with bacteria and fungi. J. Afr. Zoo. 109: 151-160.

Pegram, R.G.; Tatchell, R. J.; Castr, J. J. de; Chizyuka, H. G. B.; Creek, M. J.; Cosker, P. J. Mc; Moran, M. C. and Nigarura, G., 1993: Tick control: new concept . FAO world Animal Review :2-11.

Sayed M. A.; Habeeb, S. M. and El Kammah, K. M., 2001: Chicken immunological reaction to salivary gland proteins of Argas persicus (Oken) (Acari: Argasidae). Internal. J. Acarol. 27 (2):145-149. 